\title{
Effect of nonplastic silt content on undrained shear strength of sand-silt mixtures
}

\author{
Mohammad Emdadul Karim ${ }^{1 *}$ and Md. Jahangir Alam²
}

*Correspondence:
emdadul.buet@gmail.com
${ }^{1}$ Bangladesh University
of Engineering
and Technology, Dhaka 1000,
Bangladesh
Full list of author information
is available at the end of the
article

*Correspondence: emdadul.buet@gmail.com of Engineering and Technology, Dhaka 1000 Full list of author information article

\begin{abstract}
To assess the behavior of sand-silt mixtures, strain-controlled monotonic triaxial tests were conducted on sand-silt mixtures of specimen size $71 \mathrm{~mm}$ in diameter and $142 \mathrm{~mm}$ in height at various relative densities but same isotropic effective confining pressure of $100 \mathrm{kPa}$. Concept of limiting fines content (LFC) was verified by these undrained monotonic triaxial tests. LFC was found to be the very important parameter to understand the behavior of sand-silt mixtures. The behavior of sand-silt mixture changes approximately at LFC. At constant relative density, increase in silt content decreases the undrained peak shear strength till LFC. After LFC the strength becomes near about same till pure silt sample. The reason of behavior could not be explained. At constant global void ratio, the peak shear strength decreases with increase in silt content till LFC and for further increment of silt content the peak shear strength increases. Sand-silt mixtures containing certain amount of silt which is near to the LFC showed flow type as well as brittle behavior. Failure of structure on this type of soil will be catastrophic during earthquake. In the case of permeability decreased with increasing silt content up to LFC. After the LFC, dry density is decreasing with increasing silt content but permeability remains constant till pure silt.
\end{abstract}

Keywords: Liquefaction, Nonplastic silt, Peak shear strength, Limiting fines content, Relative density

\section{Introduction}

Nonplastic silt is a common alluvial deposit in the flood plain of Bangladesh. It is finer than sand and behaves like sand but different from elastic silt and clay. Sand and nonplastic silt are liquefiable whereas clay and elastic silt are not liquefiable. On the other hand, nonplastic silt content in sand-silt mixtures controls the behavior of the soil under monotonic and cyclic loading. Many researches are found in literature on the effect of nonplastic silt content in sand-silt mixtures. But, their findings are sometimes contradicts each other. Therefore, it is necessary to study the topic more. Moreover, design engineers are not aware of the behavior of nonplastic silt-sand mixtures.

As a result of build-up of excess pore water pressure, the effective confining pressure decreases $\left(\sigma^{\prime}=\sigma-u\right)$ triggering liquefaction. Due to the lack of drainage within very short time during earthquake, this phenomenon mainly occurs and thus the undrained testing is commonly employed by the researchers to study the liquefaction behavior of soil. 
Liquefaction behavior by cyclic loading was well observed during the earthquake in Niigata in 1964. Liquefaction may occur under static and seismic loading. For instance, slope failure at hill side and embankment due to heavy rain or dam [1] and tailing disposal failure [2] for non-cyclic loading are also liquefaction, which is termed as static liquefaction. From the experiences of past earthquakes, it is found that sandy deposits which contain significant amount of fine-grains (silty sands, clayey sands) and/or gravel liquefy during earthquakes and cause lateral spreading [3-5]. Despite this, clean sands were assumed to have similar behavior that of silty sands. That is why many researchers performed research on clean sands [6]. Afterwards, debate started that which is more liquefiable, clean sand or silty sand. The field tests, standard penetrometer and cone penetrometer tests were conducted and outlined that the higher silt content mitigates the probability of liquefaction [7, 8]. Besides, initially it was thought that the resistance of loose sand deposit improves with increasing silt content [3, 9]. Later on, Zlatovic and Ishihara [10], Thevanayagam et al. [11] and Yang et al. [12] suggested that this understanding could have limitations.

However, some studies indicated that silt content in sand increases the liquefaction potential $[13,14]$ and other specified that the resistance initially decreases as the silt content increases thereafter increases as the silt content continues to increase [15]. Besides, Kuerbis et al. [16] concluded that the presence of fines in the void spaces makes the soil slightly more dilative. Belkhatir et al. $[17,18]$ imply that the strength silty sand up to $50 \%$ fines content is less then that of the clean sand for constant dry density approach. Dash and Sitharam $[19,20]$ proposed that the strength parameter initially increases till 5\% silt content and thereafter decreases rapidly till around the limiting fines content (LFC) (explained in "Limiting fines content") and finally remain relatively constant for all the silt contents till even pure silt at constant relative density approach, though Karim and Alam [21] found this peak (for $5 \%$ silt content) when the specimens were prepared by air pluviation method not for moist temping method.

The undrained liquefaction behaviour under static and cyclic loading was generally analyzed in terms of density indices such as the relative density, $D_{r}[22,23]$ and void ratio, $e$ [24]. In this study, relative density was varied and corresponding void ratio was calculated. To explain the behavior of sand-silt mixtures and go insight, permeability tests of sand-silt mixtures were conducted. In addition, X-ray diffraction (XRD) tests were performed on clean sand and pure silt to identify percent of mica content and other minerals. Scanning electron microscopic images were studied to see the shape of the particles. Consolidated undrained static triaxial tests were performed at various relative densities and silt content.

\section{Limiting fines content}

As fines (pure silt) are added to the sand, it passes from one phase to the other through a transition point called as the limiting fines content (LFC). Below this point the soil structure is generally a sand dominated one with silt contained in a sand-skeleton whereas beyond this point there are enough fines such that the sand grains loose contact with each other and the soil structure becomes predominantly a silt dominated one. The LFC is generally calculated using the following expression [25]:

$$
L F C=\frac{W_{\text {fines }}}{W_{\text {sand }}+W_{\text {fines }}}=\frac{G_{f} e_{s}}{G_{f} e_{s}+G_{s}\left(1+e_{f}\right)}
$$


where, $W_{\text {fines }}$ is the weight of fines and $W_{\text {sand }}$ is the weight of sand in a sand-silt mixture. Similarly, $G_{f}, G_{s}, e_{f}$ and $e_{s}$. stand for specific gravity and maximum index void ratio of fines and sand, respectively.

For clarification, a hypothetic sketch is shown in Fig. 1. In Fig. 1a the microstructure of clean sand grains is exhibited. For adding certain amount of silt, the void within the sand grains fills (as in Fig. 1b). At that certain amount of silt, silt particles play an active role of separator named limiting silt content or limiting fines content (LFC). In this situation for adding more silt, sand particles state to displace from each other. Between Fig. 1b, $c$ the sand particles become significantly displaced from each other by the silt particles until reach Fig. 1d (pure silt).

Using the Eq. (1), the limiting silt content of this studied sand and silt mixtures was calculated 30\%. The LFC is normally found between 20 and 30\% for sands and non-plastic silt [26-28] and less than $20 \%$ for clay [29]. Thevanayagam et al. [11] named LFC as threshold values $\left(\mathrm{FC}_{\mathrm{th}}\right)$. When the fines content $(\mathrm{FC})$ is greater than threshold values $\left(\mathrm{FC}>\mathrm{FC}_{\mathrm{th}}\right)$, the fine grain contacts begin to play a greater role as the sand grains begin to loose contact with each other and provide a secondary reinforcement effect until they are separate sufficiently. This imposes a limiting fines content, above which the fines control the shear behavior [11]. The range of limiting fines content is very close, 1 or $2 \%$. It is very difficult to detect this range from real test. On account that in this paper the $\mathrm{LFC}$ and $\mathrm{FC}_{\mathrm{th}}$ are assumed same and for further explanation the LFC is employed only.

\section{Experimental program}

\section{Materials used and index tests}

Fine sand and silt were collected from sandbars of Padma River, Mawa, Munshiganj, Bangladesh, near Padma Bridge site. Collected samples were oven dried and then sieved through $75 \mu \mathrm{m}$ sieve to obtain the clean sands and silts. In Fig. 2 the grain size distribution of clean sand and pure silt are shown. It was tried to determine plastic limit of silt and observed that the silt is non-plastic. X-ray diffraction (XRD) tests have been performed on sand and silt, at a scanning speed of $0.02^{\circ}(2 \theta) \mathrm{s}^{-1}$ by using a CuK $\alpha(1.542 \AA)$ radiation range of $5^{\circ}$ to $65^{\circ}$. The name of compound, percent (by atomic weight) and formula of each of the minerals in sands and silts are presented in Table 1. It was found that there was no mica in sand whereas $4 \%$ mica was found in silt. What is more, silt contains $8 \%$ clay mineral while it showed nonplastic behavior in Atterberg limit test. Index properties of sands and silts are shown in Table 2. Clean sand and silt specimens were

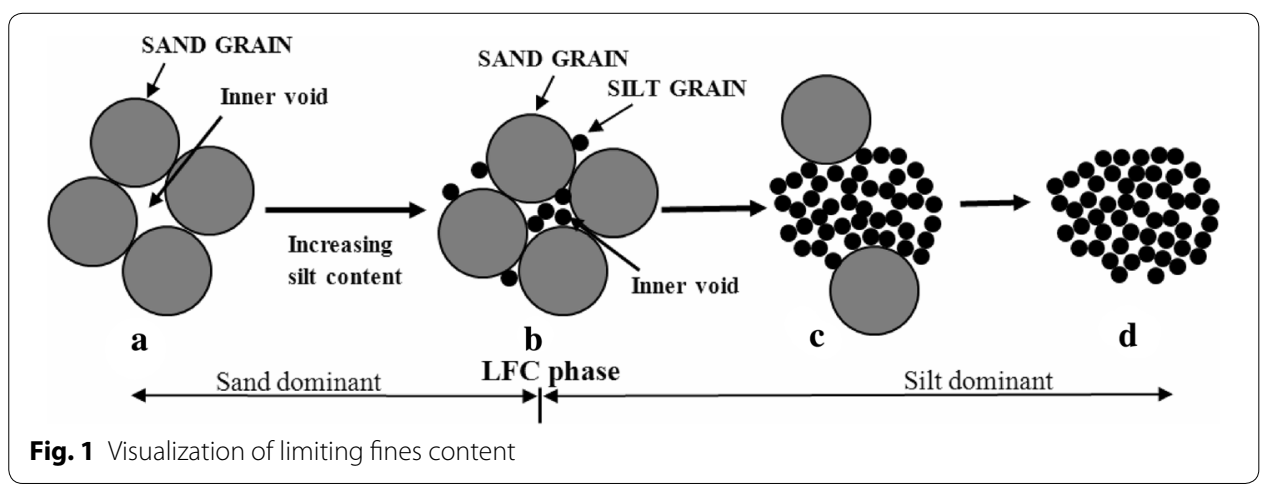




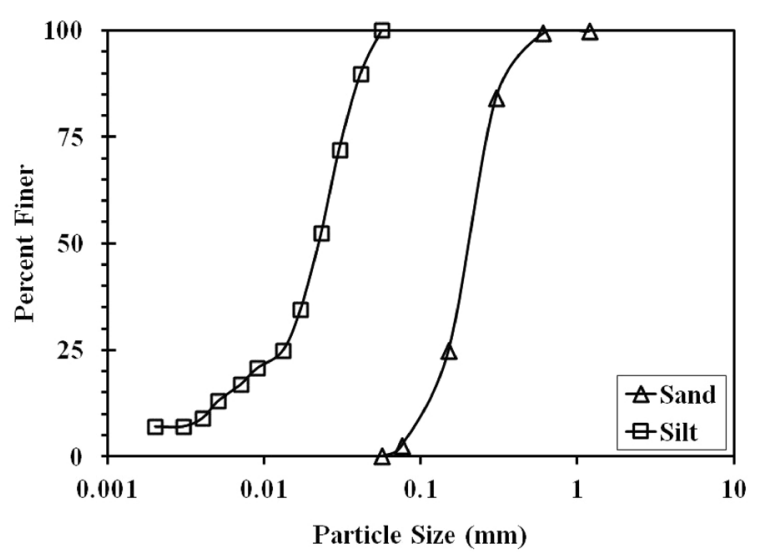

Fig. 2 Grain size distribution of samples used in this study

Table 1 Quantitative X-RD test result

\begin{tabular}{llcl}
\hline & Compound name & Percent (\%) (by atomic weight) & Formula \\
\hline Sand & Quartz & 81.10 & $\mathrm{SiO}_{2}$ \\
& Albite & 11.28 & $\mathrm{Na}\left(\mathrm{AlSi}_{3} \mathrm{O}_{8}\right)$ \\
& Feldspar & 7.62 & $\mathrm{~K}_{0.5} \mathrm{Na}_{0.5} \mathrm{AlSi}_{3} \mathrm{O}_{8}$ \\
Silt & 66.62 & $\mathrm{SiO}_{2}$ \\
& Quartz & 5.72 & $\left(\mathrm{Mg}_{1} \mathrm{Al}\right)_{6}\left(\mathrm{Si}, \mathrm{Al}_{4} \mathrm{O}_{10}(\mathrm{OH})_{8}\right.$ \\
& Chlorite & 8.24 & $\mathrm{Na}\left(\mathrm{AlSi}_{3} \mathrm{O}_{8}\right)$ \\
& Albite & 8.11 & $\left(\mathrm{~K}_{1} \mathrm{H}_{3} \mathrm{O}\right) \mathrm{AlSiAlO}_{10}(\mathrm{OH})_{2}$ \\
Clay mineral: Illite & 4.35 & $\mathrm{Kal}_{2}\left(\mathrm{AlSi}_{3} \mathrm{O}_{10}\right)(\mathrm{OH})_{2}$ \\
& Mica: Muscovite & 4.89 & $\mathrm{Mg}_{3.4} \mathrm{Si}_{2.85} \mathrm{Al}_{1.1} \mathrm{O}_{10}(\mathrm{OH})_{2}\left(\mathrm{H}_{2} \mathrm{O}\right)_{3.7}$ \\
& Vermiculite & 2.07 & $\mathrm{Mg}_{0.8} \mathrm{Fe}_{0.2}\left(\mathrm{SiF}_{6}\right)\left(\mathrm{H}_{2} \mathrm{O}\right)_{6}$ \\
\hline
\end{tabular}

Table 2 Index properties of sand and silt used in the study

\begin{tabular}{lll}
\hline Soil type & Clean sand & Pure silt \\
\hline USCS classification symbol & Poorly graded sand & Silt \\
Mean grain size $D_{50}(\mathrm{Mm})$ & 0.203 & 0.022 \\
Uniformity coefficient $\left(C_{u}\right)$ & 2.25 & 5.82 \\
Coefficient of gradation $\left(C_{z}\right)$ & 1.17 & 2.15 \\
Specific gravity $\left(G_{s}\right)$ & 2.69 & 2.72 \\
Liquid limit $(\%)$ & $\mathrm{NP}$ & 38 \\
Plastic limit $(\%)$ & $\mathrm{ND}$ & $\mathrm{ND}$ \\
Plasticity index $(\%)$ & $\mathrm{NP}$ & $\mathrm{NP}$ \\
\hline
\end{tabular}

$N P$ non-plastic, $N D$ not determinable

viewed under scanning electron microscope (SEM) to see the shape of particles which are shown in Fig. 3. From these two images, it is clearly seen that the fine sand and silt particles are angular and rough.

The vibration table method [30] is limited to a maximum fines content of $15 \%$, while Proctor tests do not always produce accurate, repeatable results for clean sands. Therefore, vibration table and standard and modified Proctor tests were all performed upon each soil mixture. In agreement with the findings of Lee and Fitton [31], the vibration 


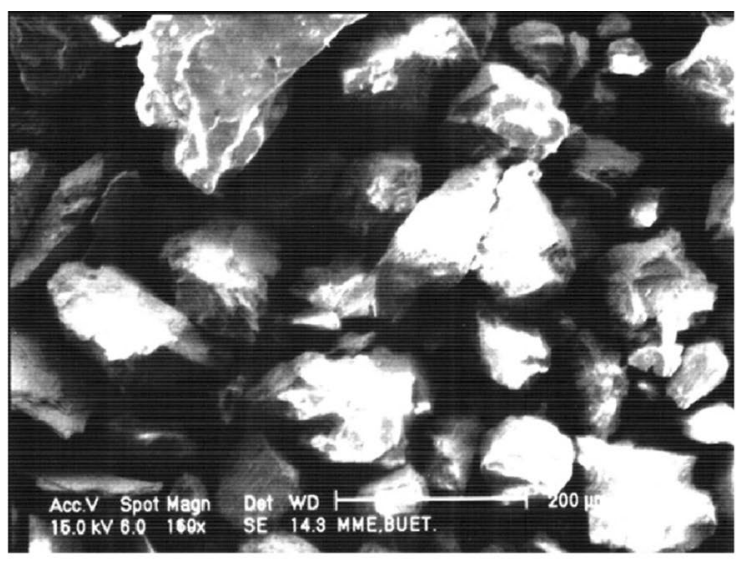

$\mathbf{a}$

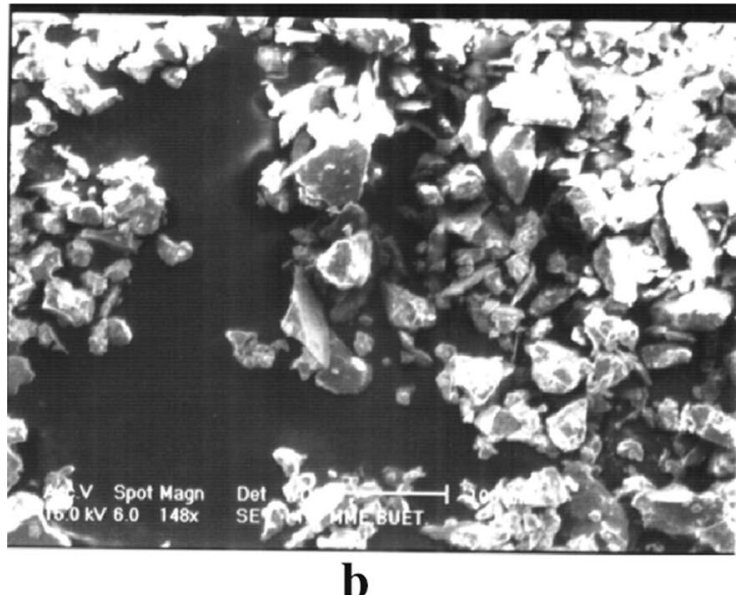

Fig. 3 Scanning electron microscopic view of (a) clean sand and (Scale $200 \mu \mathrm{m})$, b pure silt used in this study (Scale $100 \mu \mathrm{m}$ )

table tests yielded maximum dry densities similar to those produced by the modified proctor test. So, modified proctor test was used for all samples to determine maximum dry density. Minimum index dry density was determined by minimum density test using free fall in water method [32]. In Fig. 4, maximum dry density increased with increase in silt content thereafter decreased; on the other hand minimum dry density decreased with increase in silt content. This minimum dry density line (decreasing with increase in silt content) was different from other researcher [19, 20, 33], because the minimum density tests were conducted by Water method.

\section{Specimen preparation and placing}

Soil specimens used in this study were of $71 \mathrm{~mm}$ in diameter and $142 \mathrm{~mm}$ in height. In moist tamping method the soil structure is homogenous. So the specimens were formed by using moist tamping method in a split mold. Firstly, desire amount of dry sample was taken and $10 \%$ of water (percent of dry weight of soil) was mixed. Afterwards, the moist soil was divided (by weight) into target number of layers. Then each weighted moist soil sample was poured into the split mold and compacted. Number of layers and blows per 


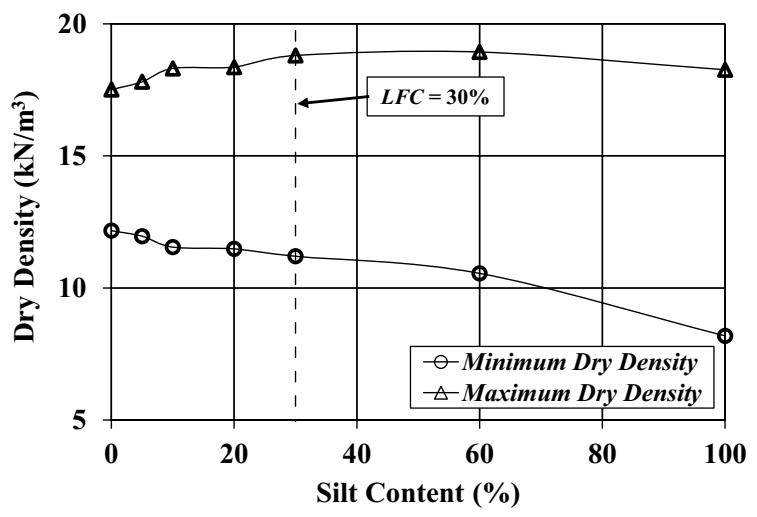

Fig. 4 Variation of maximum and minimum index dry density of sand-silt mixtures

layer were determined by trial to achieve target relative density. The weight of hammer was $1 \mathrm{~kg}$ and had a drop height of $150 \mathrm{~mm}$. In order to obtain a uniform density throughout the specimen, the compaction method of specimen preparation suggested by Ladd [34] was followed.

When the sample preparation was completed, it was gripped by membrane after placing the filter paper and porous stone both sides, top and bottom. The height of the membrane was maintained two times as much as the sample so that it can cover the top sample cap and sample base grooves. Afterwards, the gripped sample with filter papers and porous stones were placed on sample base. The sample cap with screwed piston rod was kept on the sample. Next, unfolding of extra portion of membrane at top and bottom were done and o-rings were placed in the grooves which were already covered by membrane. Once the cell chamber was assembled, it was filled with water. To confirm the close contact between the load sensor and piston rod a negligible amount of force was applied.

Cyclic and static triaxial tests can be conducted by this machine. In cyclic loading the upper force actuator is activated whereas the lower actuator for static loading. In this triaxial machine all sensors are external and the pipes of same diameter (in the cell chamber and outside) were used to remove the head loss due to sudden expansion or contraction of pipe line. What is more, two pipe lines came out, one from top cap of the sample, other from bottom and ended connecting into a single pore pressure measuring transducer. That means while test runs the top and bottom pore pressure will be mixed up which will provide the average pore pressure inside the sample. Besides, from this sample base, a pipe came where back pressure is applied. The axial displacement transducer was placed beneath the ramp of the cell chamber.

\section{Saturation, consolidation and monotonic axial load}

Initial saturation of the specimen was done by passing carbon dioxide $\left(\mathrm{CO}_{2}\right)$ about one hour through the specimen. Afterwards, distill water was passed through the specimen by gravity pressure (nearly $5 \mathrm{kPa}$ ) for $3-5 \mathrm{~h}$. At that moment, $20 \mathrm{kPa}$ confining pressure was maintained. Ending this process the saturation phase was started. The machine is capable of applying sufficient back pressure till it was ensured that the Skempton's B parameter equal to 0.95 . The specimens were then isotropically consolidated to a desired 
effective confining stress of $100 \mathrm{kPa}$. The duration for the process of consolidation was varied from about $0.5 \mathrm{~h}$ (for clean sands) to about $2 \mathrm{~h}$ (for pure silt). All relative densities reported here were calculated prior to consolidation. After consolidation undrained monotonic axial load was applied at a strain rate $0.05 \%$ per minute till maximum axial strain 15\% (ASTM-D4767-02) [35]. The static undrained tests were conducted at slower rate, so that the loading or excess pore water pressure can uniformly transfer into the whole soil specimens (or soil structure).

\section{Specimen for permeability test}

The permeability tests were conducted by falling head method. At the beginning 10 percent of water (by weight of soil) was mixed with oven dry soil sample. Thereafter the moist soil sample was divided into four equal weights. Each portion was poured into $64 \mathrm{~mm}$ diameter permeameter cell and compacted by hammer. The height of the specimen was kept $85 \mathrm{~mm}$. In order to obtain a uniform density throughout the specimen, the compaction method of specimen preparation suggested by Ladd [34] was used. $\mathrm{CO}_{2}$ was applied through the specimen from the bottom pipe of falling head permeability apparatus. Later water was passed through the same pipe until the sample fully submerged and water comes out through the upper pipe. To get better saturation ratio the sample was kept submerged into the permeameter cell for $24 \mathrm{~h}$. In this way it is possible to get the saturation ratio near about 0.89 [36].

\section{Results and discussion}

The undrained monotonic triaxial tests were performed on sand-silt mixtures at 30, 60 and $78 \%$ relative densities (initial relative density) and effective isotropic confining pressure of $100 \mathrm{kPa}$. A total of 30 undrained monotonic triaxial tests have been conducted and the test program is given in Table 3. Here, to explain the results, the percent of silt content is considered as parameter. For instance, a sample prepared by mixing $80 \%$ sand and $20 \%$ silt was addressed by $20 \%$ silt content sample.

\section{Effect of initial saturation and consolidation}

The $30 \%$ relative density is very loose condition. By moist temping method with $10 \%$ moisture content, specimen of $30 \%$ relative density was possible to prepare, as between each grain there is a little blob of water (due to $10 \%$ moisture content) and the surface

Table 3 Program of undrained monotonic triaxial test

\begin{tabular}{|c|c|c|c|}
\hline Soil type (named) & Relative density, $D_{r}(\%)$ & $\begin{array}{l}\sigma_{3 c}^{\prime} \\
\text { (Кра) }\end{array}$ & Total no. of experiment \\
\hline Clean sand & $30,36,40,60$ & 100 & 5 \\
\hline $90 \%$ sand $+10 \%$ silt & $30,50,60$ & 100 & 3 \\
\hline $80 \%$ sand $+20 \%$ silt & $30,60,67,78$ & 100 & 5 \\
\hline $70 \%$ sand $+30 \%$ silt & $30,60,74,78$ & 100 & 4 \\
\hline $65 \%$ sand $+35 \%$ silt & $60,68,78$ & 100 & 3 \\
\hline $40 \%$ sand $+60 \%$ silt & $30,60,78$ & 100 & 3 \\
\hline $10 \%$ sand $+90 \%$ silt & $60,78,82$ & 100 & 3 \\
\hline \multirow[t]{2}{*}{ Pure silt } & $30,60,70,78$ & 100 & 4 \\
\hline & & Total & 30 \\
\hline
\end{tabular}


tension. During initial saturation phase, after applying $\mathrm{CO}_{2}$, distilled water was passed through the specimen. When the water was passing through the specimen the water saturation makes surface tension force zero and the whole structure rearranged $[37,38]$ causing the wrinkles on the surface of the membrane of 60 and $100 \%$ silt content specimens (see Fig. 5a, b). In Fig. 5a(1) and 5b(3) the vertical wrinkles appeared when water was passing through the 60 and $100 \%$ silt content specimens, respectively. In the following stage (at shearing), a lot of horizontal wrinkles appeared presented in Fig. 5a(2) and $5 \mathrm{~b}(4)$ for 60 and $100 \%$ silt content specimens, respectively. The dry densities of 60 and $100 \%$ silt content specimens were 12.21 and $9.85 \mathrm{kN} / \mathrm{m}^{3}$, respectively. More wrinkles were found on pure silt specimen [see Fig. $5 b(3)$ ] than $60 \%$ silt content specimen [see Fig. 5a(1)]. In the initial saturation (while the water was passing) the effective pressure was near about $15 \mathrm{kPa}$ (cell pressure $20 \mathrm{kPa}$ and back pressure $5 \mathrm{kPa}$ ). The volumetric strain during initial saturation phase (for effective pressure $15 \mathrm{kPa}$ ) for $60 \%$ silt

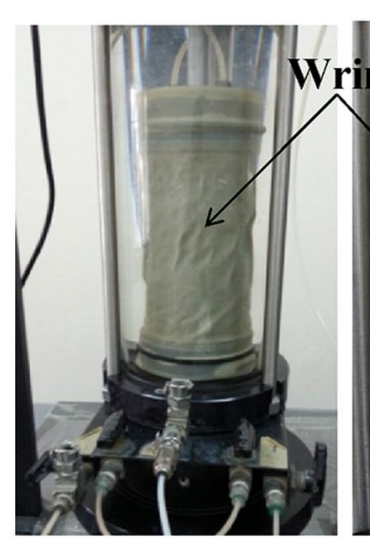

1) Before Shear Loading

$\mathbf{a}$

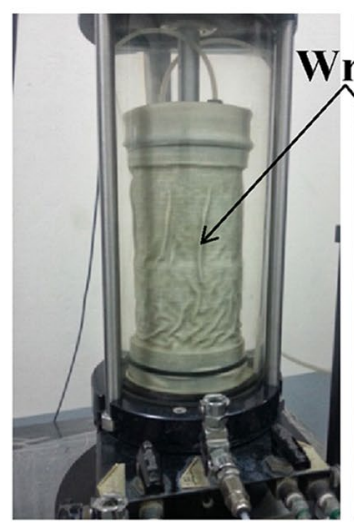

3) Before Shear Loading

\section{2) After Shear Failure}

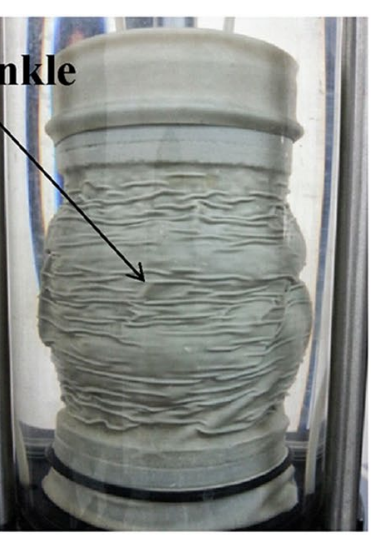

\section{a}


content and pure silt specimens (at 30\% initial relative density) were measured from the cell volume change and used to calculate the final relative density. Relative density of 60 and $100 \%$ silt content specimens prepared at 30\% relative density became 45 and 55\% respectively, after initial saturation. For the specimens of equal and less than $30 \%$ silt content, this initial consolidation was not significant and wrinkles in membrane was not appeared on those specimens. That means, at 30\% initial relative density, particle arrangement of 60 and 100\% silt content specimens are very much unstable. Practically, this relative density is not possible for alluvial deposits of silt which formed in water submerged condition.

When B-value 0.95 reached, the consolidation was started at $100 \mathrm{kPa}$ all around confining pressure. In Fig. 6, the consolidation graphs of sand-silt mixtures are shown for different initial relative densities. As expected, volumetric strain decreased with the increasing initial relative density. For same relative density, volumetric strain also increased with the amount of silt content in sand-silt mixture. The summarized results of volumetric strain at $100 \mathrm{kPa}$ consolidation pressure are shown in the Fig. 7. It is observed that at $30 \%$ initial relative density, an increase in fines content increases the compressibility [39] till pure silt. What is more, the rate of volumetric strain also increased with the amount of silt content [39]. In case of specimens of initial relative density $60 \%$ the volumetric strain increased till LFC. Afterwards, it was nearly same till pure silt. However, at $78 \%$ relative density, volumetric strain during consolidation is not significant.

\section{Constant relative density method}

Three initial relative densities, 30, 60 and 78\%, were maintained for sand-silt mixtures under this research work and the behavior of sand-silt mixtures for each density is explained separately.

\section{Response at $30 \%$ relative density}

The Fig. 8 shows the deviator stress versus axial strain graph of sand-silt mixtures. Here initially the deviator stresses increased with axial strain. For all specimens containing silt less than or equal to $30 \%$, the peak deviator stress appeared when the axial strain was near about 1\%. Later, it decreased with increasing axial strain. This behavior is named as "flow type" by Ishihara [40]. "Flow type" behavior was dominant for 10, 20 and 30\% silt content specimens whereas for clean sand it was not significant. For $60 \%$ silt content specimen "flow with limited deformation" [40] was observed. In case of pure silt, non-flow or dilative behavior was observed. Because, changes of relative density during saturation and consolidation phase were significant for 60 and 100\% silt content specimens. Relative density of 60 and $100 \%$ silt content specimen became 50 and $65 \%$ respectively after completion of consolidation whereas relative density of other specimens were 34-37\%.

Yamamuro and Lade [41] examined the liquefaction resistance by plotting the brittleness index $\left(I_{B}=q_{\min } / q_{I S}\right)$ concept. Where, $q_{I S}$ the peak deviator stress at the beginning of instability and $q_{\min }$ is the minimum deviator stress attained after the $q_{I S}$. For $q_{\min } / q_{I S}=0$, the specimen shows flow liquefaction behavior and stable behavior for $q_{\min } / q_{I S} \rightarrow 1$. The brittleness index versus percent of silt content graph is shown in Fig. 9. Here, the relative density after consolidation is denoted as $D_{r(a)}$. With reference to this graph, the $I_{B}$ 


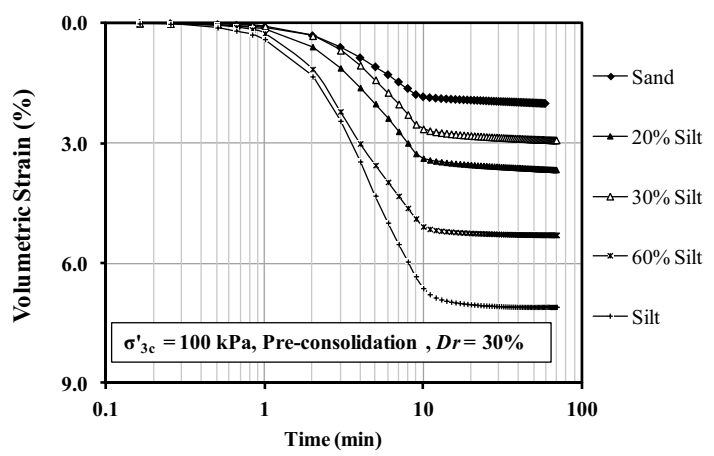

a

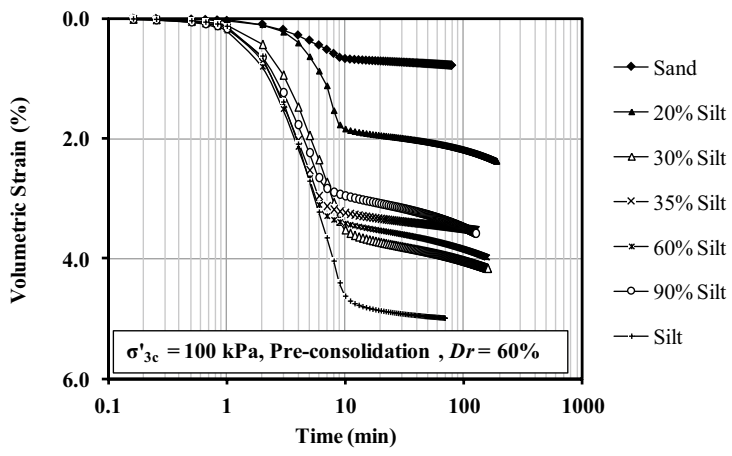

b

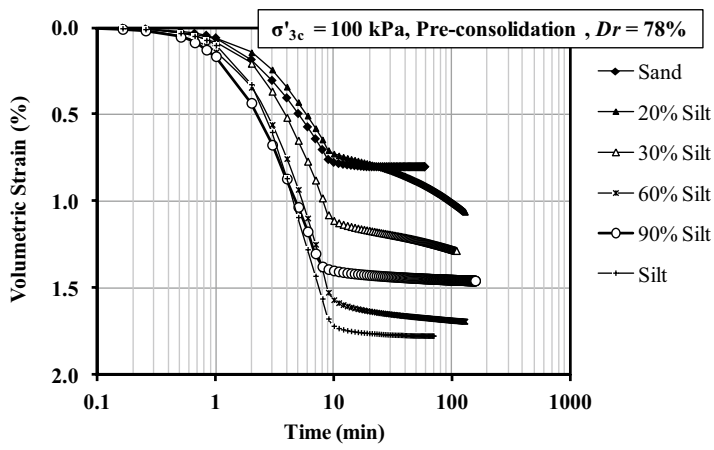

c

Fig. 6 Consolidation of sand-silt mixtures prepared at relative density. a 30\%, b $60 \%$ and c $78 \%$

decreased with increasing silt content up to $20 \%$ and increased again. The $I_{B}$ for sand is nearly 0.78 but for 10,20 and $30 \%$ silt content specimens the values were below 0.5 . That means, the failure was more catastrophic for 10, 20 and 30\% silt content specimens than clean sand. In contrast, due to consolidation (initial at $15 \mathrm{kPa}$ and final at $100 \mathrm{kPa}$ ) $60 \%$ silt and $100 \%$ silt content specimens became more dense and stable. That is why, the $I_{B}$ for $60 \%$ silt and pure silt are close to 1 .

Excess pore water pressures of same specimens are exhibited in the Fig. 10. It increased substantially for all samples except pure silt. Besides, the excess pore pressure generation rate was slower in pure silt compared to other specimens. Because, relative density of pure silt was $65 \%$. Within $2 \%$ axial strain $80 \mathrm{kPa}$ of excess pore water pressure was developed in the specimens. Maximum pore pressure was $100 \mathrm{kPa}$ which generated in 30\% 


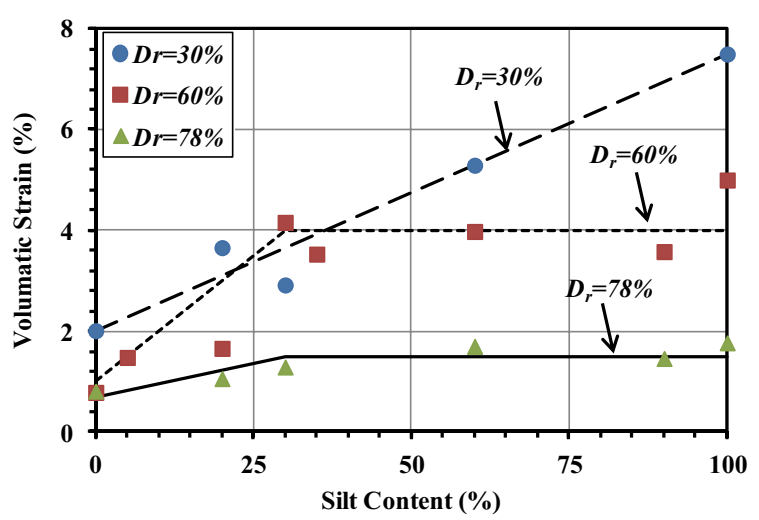

Fig. 7 Volumetric strain of specimen during consolidation phase

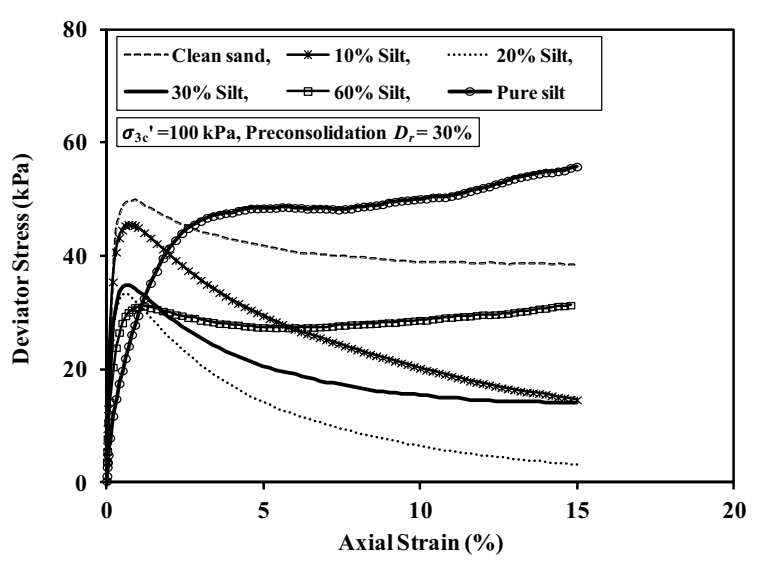

Fig. 8 Stress-strain relationship at 30\% relative density

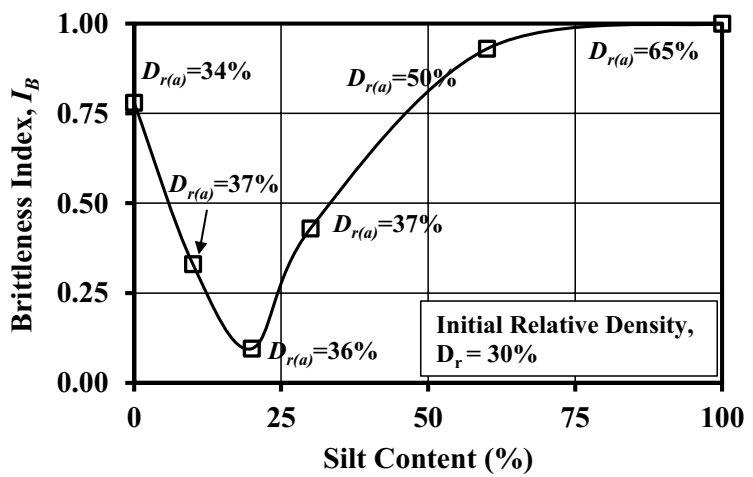

Fig. 9 Brittleness index of sand-silt mixtures at initial relative density, $D_{r}=30 \%$

silt content specimen. The pore pressure of each specimen became constant after reaching 5\% axial strain. At $34-37 \%$ relative density all the specimens of sand-silt mixtures showed contractive behavior irrespective of silt content, as positive excess pore pressure generated for all specimens [42]. 


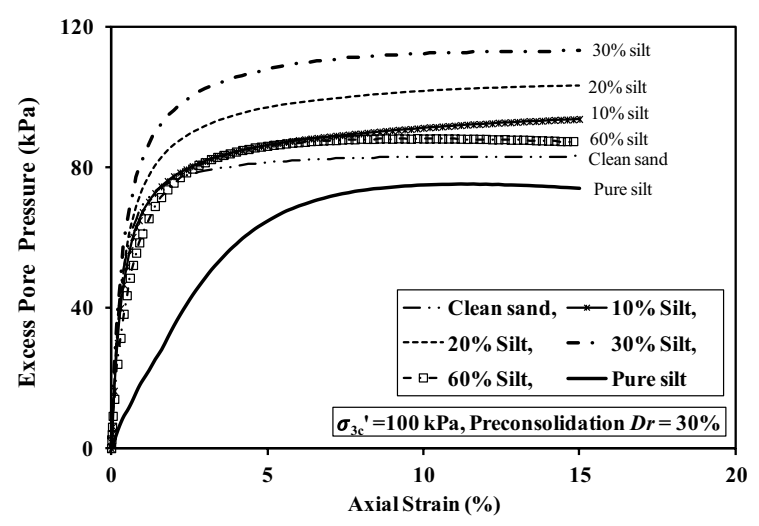

Fig. 10 Excess pore pressure versus strain curve at 30\% relative density

The effective stress path is shown in Fig. 11 on the $p^{\prime}-q$ diagram, where $p^{\prime}$ is assigned to horizontal axis and $q$ is plotted on the vertical axis. The effective failure line and effective failure angle are also shown here. These effective stress paths again proved that all the specimen of the sand-silt mixtures showed contractive behavior which may be termed as static liquefaction [41]. On the other hand, silt content more than LFC showed contractive behavior having quasi steady state point which is termed as temporary instability [41]. The average angle of effective failure line is calculated as $27^{\circ}$.

The undrained monotonic peak shear strength versus silt content for initial relative density of $30 \%$ is plotted in Fig. 12. The post consolidation relative density of each tested specimen is also shown here. It presents that the peak shear strength decreased with increasing percent of silt content till $30^{\circ}$ silt content (LFC). For 60 and $100 \%$ silt content, post consolidation relative density was significantly different with other specimens. So,

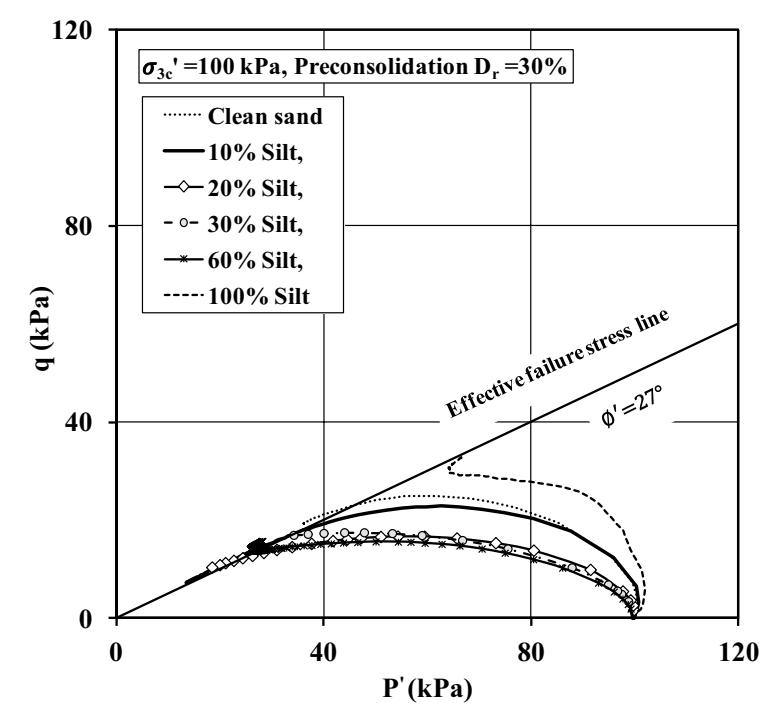

Fig. 11 Effective stress path of tested specimens at 30\% relative density 
these two specimen result could not be used explained here. In the consolidation phase for $100 \mathrm{kPa}$ confining pressure the pure silt specimen became denser, greater than $60 \%$, as a result it exhibited more shear strength than that of other specimens.

\section{Response at $60 \%$ relative density}

A total of 10 undrained monotonic triaxial tests were conducted on sand-silt mixtures at a initial relative density of $60 \%$. The stress-strain response of these specimens is presented in Fig. 13a and b. Figure 13a illustrates two types of stress-strain behavior obtained from undrained shear tests on saturated and consolidated samples of sand-silt mixtures at $60 \%$ relative density. When it was clean sand, the sample displayed strainhardening behavior where the shear stress always went up with increasing axial strain. The clean sand, in such state is referred to as being dilative or non-flow type behavior [40]. The sand mixed with $10 \%$ silt also exhibited the similar type of behavior but showing less shear strength than that of clean sand. When the silt content was greater than $20 \%$ (Fig. 13b), the strain-softening behaviors were exhibited by the samples. In 20, 30 and 35\% specimens the deviator stress declined over the axial strain (1-15\%) significantly whereas this behavior less dominant in 60 and $100 \%$ silt content specimens.

Brittleness index of sand-silt mixtures at $60 \%$ initial relative density is plotted in Fig. 14. Brittleness index $\left(I_{B}\right)$ (Fig. 14) decreased with increasing silt content up to $35 \%$ silt content and increased after $35 \%$ silt content.

The excess pore pressure response of sand-silt mixture with $0-100 \%$ silt content is shown in Fig. 15. For clean sand and 10\% silt content (Fig. 15a), initially the excess pore water pressure increased till $2 \%$ axial strain and for further strain it decreased, it made them to appear contractive behavior initially afterwards dilative. Besides, the rate of decreasing excess pore pressure was higher for clean sand than that of $10 \%$ silt content specimen. It means that increasing fines content decreases the rate of generation of negative excess pore water pressure. At $60 \%$ relative density all the specimen of sandsilt mixtures except clean sand and $10 \%$ silt content showed contractive behavior, since positive excess pore pressure generated in those specimens. For sand-silt mixtures, with $20-100 \%$ silt content (Fig. 15b) the excess pore pressure increased with increasing axial strain up to $5 \%$ axial strain, after that all became steady. Excess pore pressure generation

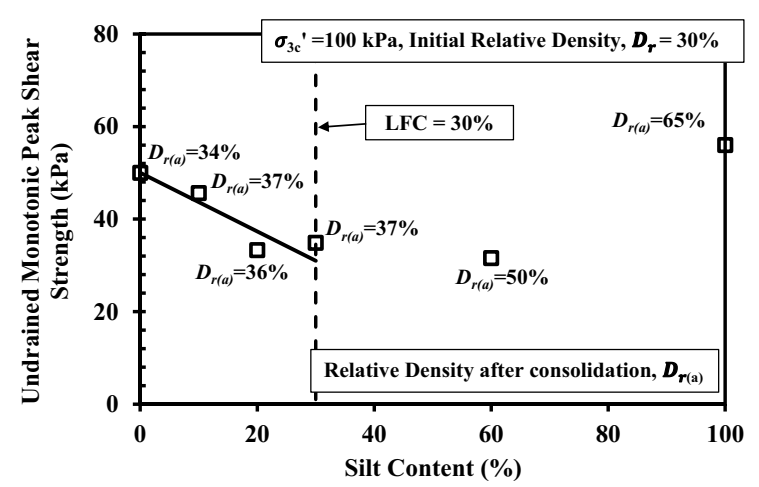

Fig. 12 Effect of silt content on undrained monotonic peak shear strenght of sand-silt mixtures at Canstant initial relative density of $30 \%$ 

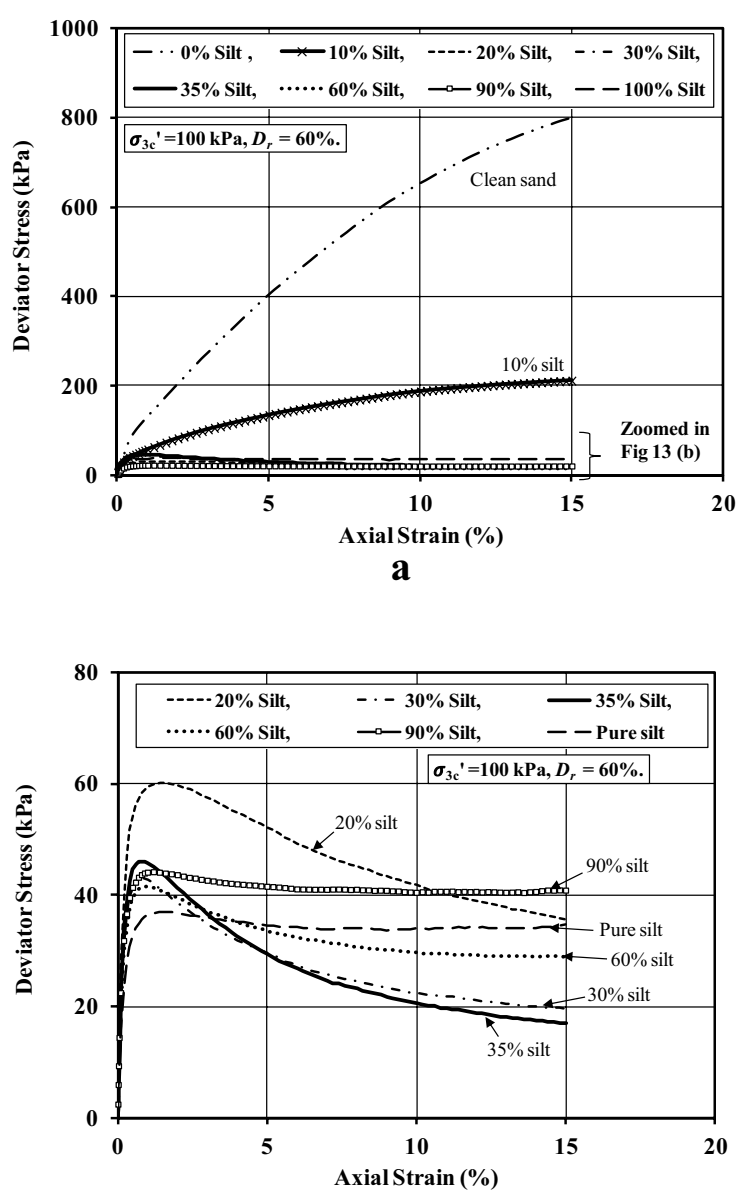

b

Fig. 13 Stress-strain relationship at 60\% initial relative density; a silt content 0-100\% and $\mathbf{b}$ silt content $20-100 \%$ silt

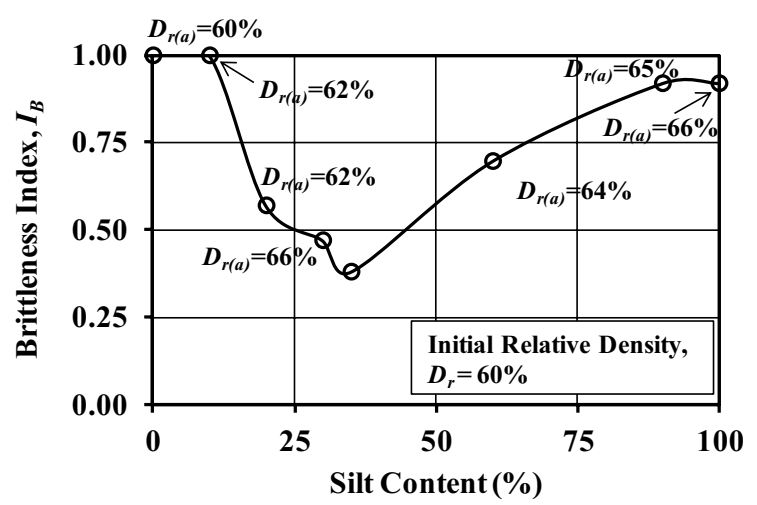

Fig. 14 Brittleness index of sand-silt mixtures at initial relative density, $D_{r}=60 \%$ 


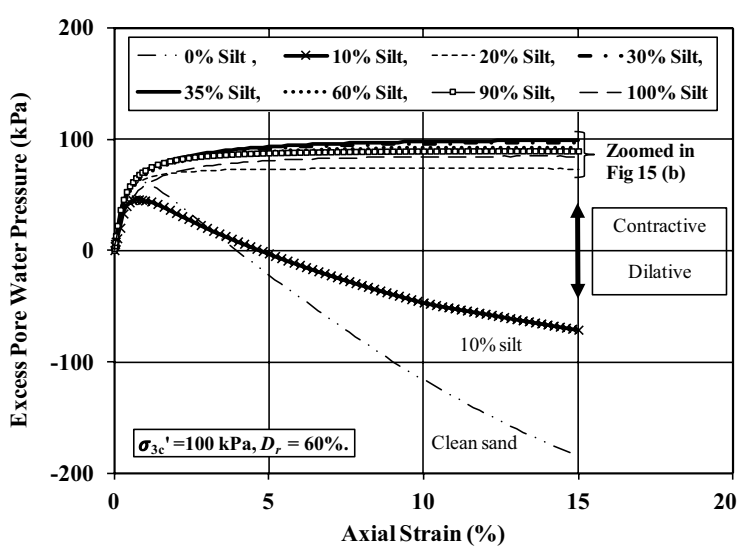

a

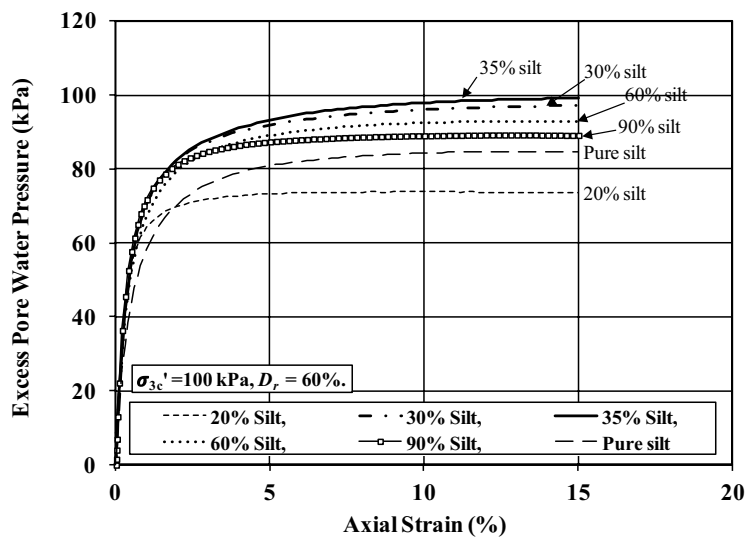

b

Fig. 15 Excess pore pressure versus strain curve at 60\% initial relative density; $\mathbf{a}$ silt content $0-100 \%$ and $\mathbf{b}$ silt content $20-100 \%$ silt

was found maximum for 30 and $35 \%$ silt content specimens where the effective pressures reached to nearly zero.

In Fig. 16 the effective stress path of sand-silt mixtures at $60 \%$ relative density is shown. The angle of effective failure line is calculated about $31^{\circ}$ The effective stress paths of clean sand and $10 \%$ silt content sample (Fig. 16a) were seen to deviate upwards from phase transformation point increasing the strength which is termed as stable behavior [41]. For $20 \%$ silt content, the stress path neither decreased nor increased after touching the failure line. The samples having $20-100 \%$ silt content (see Fig. 16b), showed the contractive behavior which is called static liquefaction by Yamamuro and Lade [41].

The undrained monotonic peak shear strength of sand-silt mixtures (initial relative density $60 \%$ ) with post consolidation relative density is exhibited in Fig. 17. The relative density increased near about $1-2 \%$ for sand dominant part's specimens and $4-6 \%$ for silt dominant part's specimens. The shear strength decreased with increasing silt content till LFC, after LFC the strength became constant up to pure silt content. 


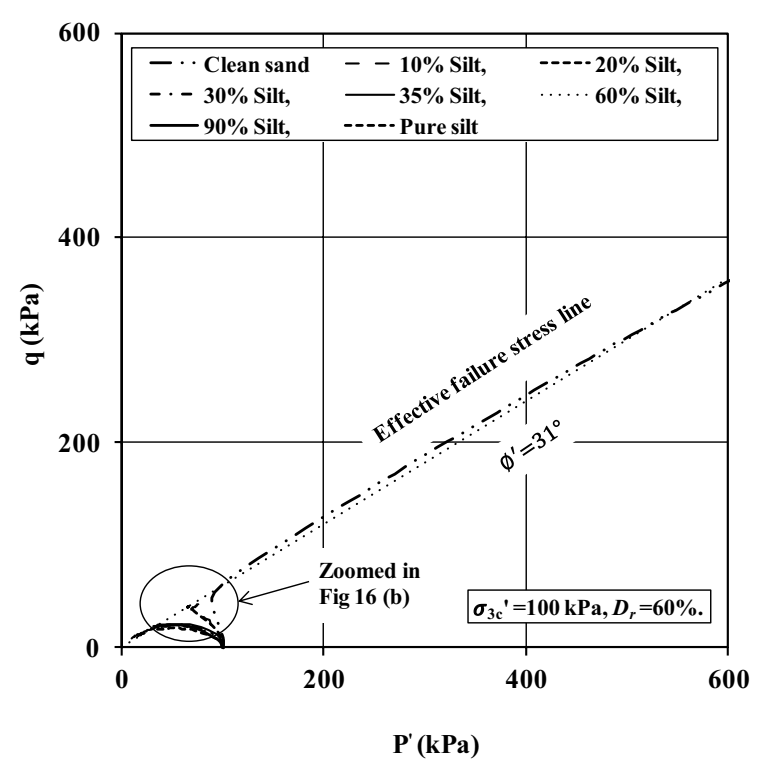

a

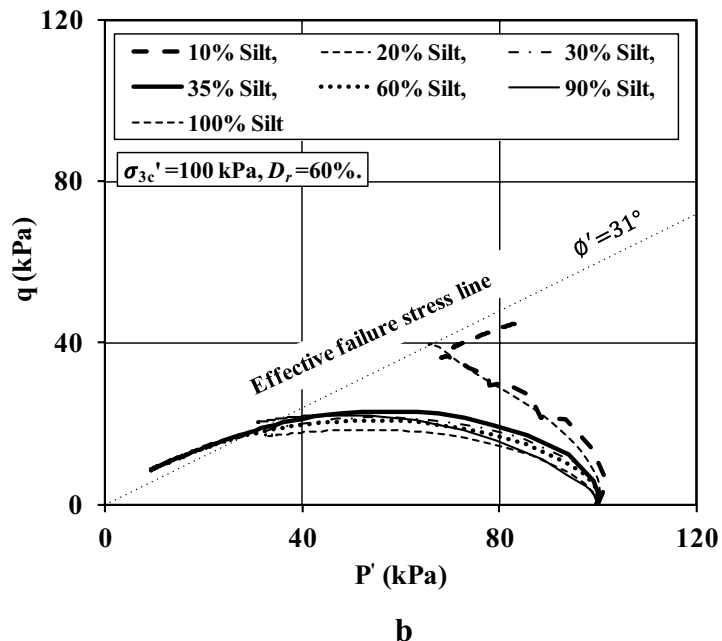

Fig. 16 Effective stress path of tested specimens at 60\% initial relative density; a silt content $0-100 \%$ and $\mathbf{b}$ silt content $20-100 \%$ silt

\section{Response at $78 \%$ relative density}

A total of seven undrained monotonic triaxial tests have been performed on sand-silt mixtures with an initial relative density of $78 \%$ After consolidation, the relative density increased about $1-2 \%$ for all these specimens. The stress-strain response of these specimens is presented in Fig. 18a and b. The capacity of the triaxial test machine exceeded, what make the author to stop the test of clean sand (Fig. 18a) of initial relative density $78 \%$ after reaching $4.5 \%$ axial strain, at that point the deviator stress was $1030 \mathrm{kPa}$. Elasto-plastic behavior was appeared at $20 \%$ silt content specimen. But in Fig. 18a it can be seen that all specimens exhibit elasto-plastic behavior except $35 \%$ silt content specimen. In other word, all specimens showed strain-hardening except 20, 30 and 35\% silt 


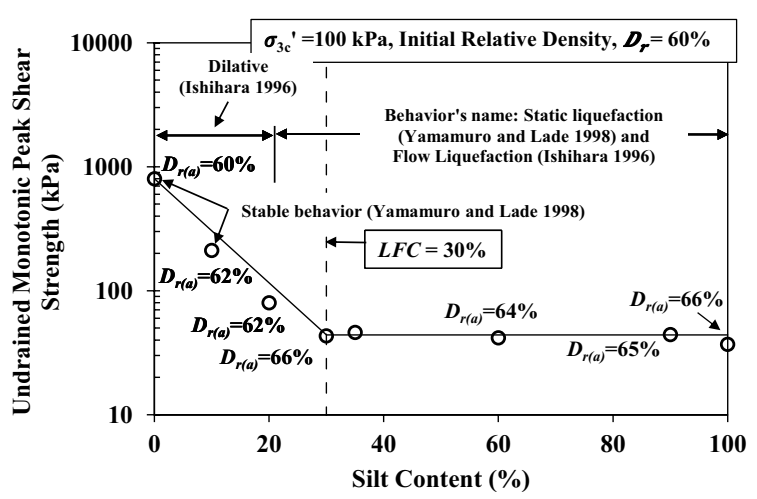

Fig. 17 Effect of silt content on undrained monotonic peak shear strength of sand-silt mixtures at Canstant initial relative density of $60 \%$

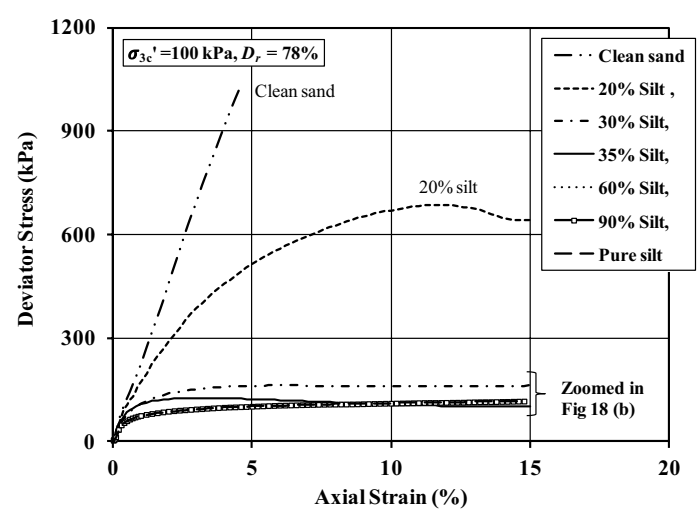

a

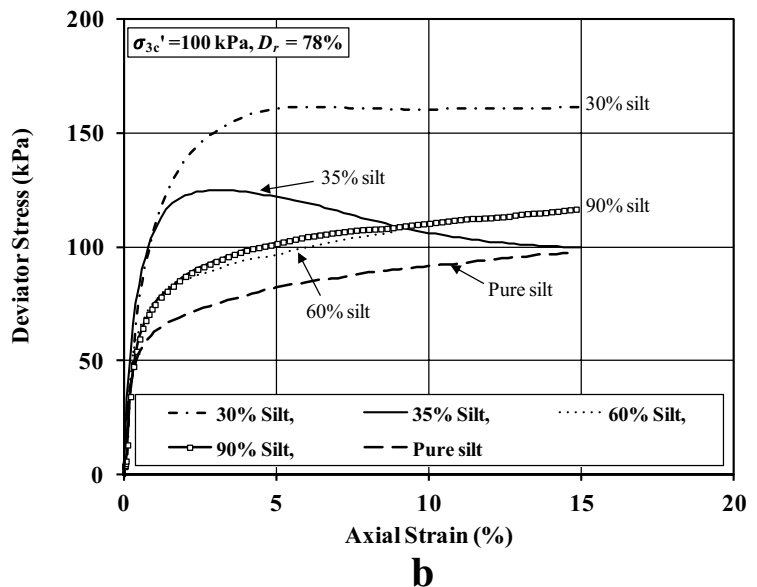

Fig. 18 Stress-strain relationship at 78\% relative density; a silt content $0-100 \%$ and b silt content $30-100 \%$ silt

content specimens. Brittleness index of $78 \%$ relative density specimens are plotted in Fig. 19. All the specimens showed stable behavior except slight brittle behavior of 20 and $35 \%$ silt content specimens. 


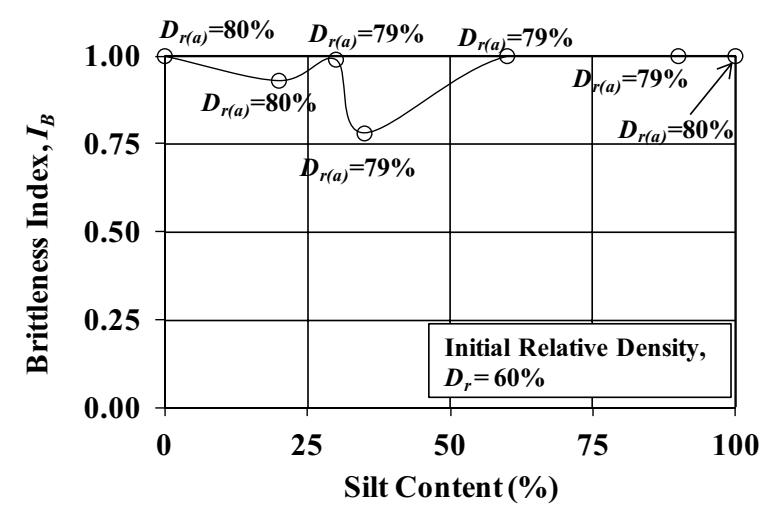

Fig. 19 Brittleness index of sand-silt mixtures at initial relative density, $D_{r}=78 \%$

Figure 20a and $\mathrm{b}$ shows excess pore water pressure response of sand silt mixtures of pre-consolidation relative density 78\%. Referring this Fig. 20a, for clean sand and 20\% silt specimens the excess pore water pressure increased rapidly due to loading until

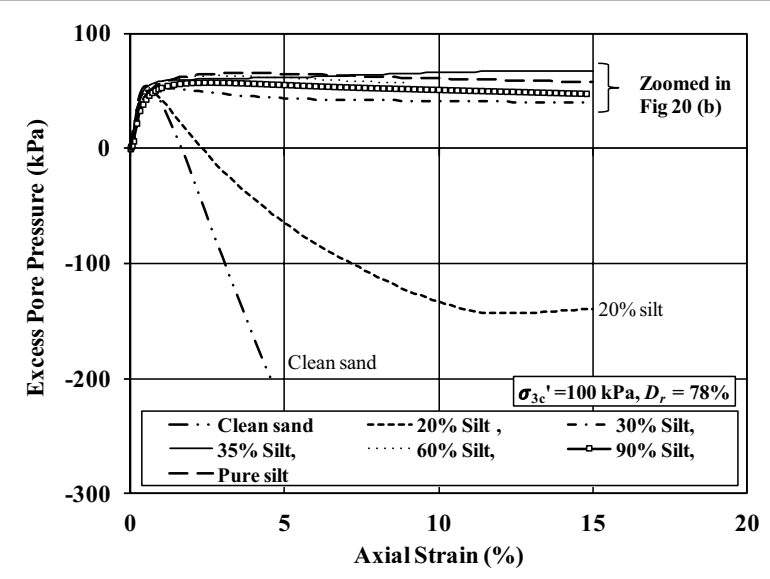

a

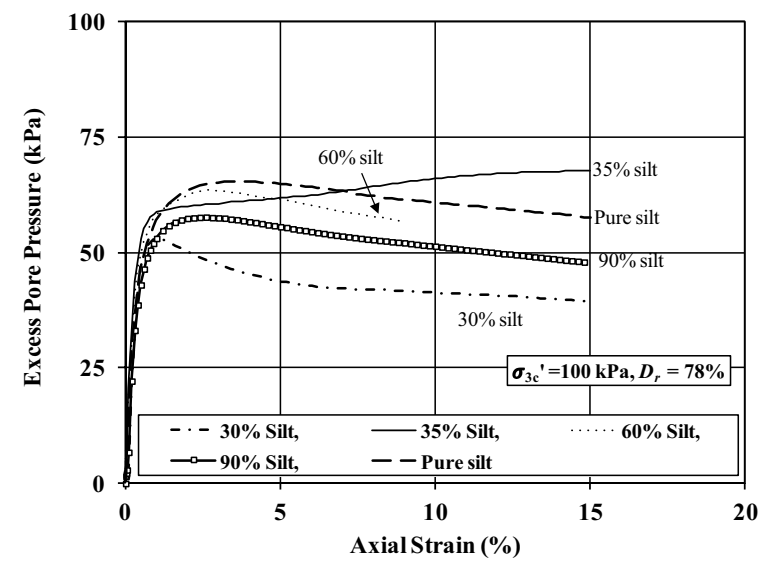

b

Fig. 20 Excess pore pressure versus strain curve at 78\% relative density; a silt content $0-100 \%$ and $\mathbf{b}$ silt content $30-100 \%$ silt 
nearly $1 \%$ axial strain. For further strain the negative excess pore pressure generated. The negative excess pore water pressure became constant after $11 \%$ axial stain, for $20 \%$ silt content specimen whereas for clean sand specimen, the maximum loading capacity of triaxial test machine was reached that is why no further value was able to measure after 4.5\% stain. The values for other specimens are not clear in Fig. 20a, therefore in Fig. 20b those are shown. Concerning this figure, accept $35 \%$ silt content specimen, the excess pore water pressure started to decline gradually after sharp increasing due to increase of axial stain. Consequently, in all specimens, initially contractive (increase of excess pore water pressure) behavior was exhibited afterwards dilative (decrease of excess pore water pressure). Besides, it increased for $35 \%$ silt content specimen till $15 \%$ axial strain. Though, initially the excess pore pressure grew sharply till 1\% axial strain later slowly. It means just the contractive behavior is observed in this specimen.

Figure 21 illustrates the effect stress path of sand-silt mixtures of pre-consolidation relative density $78 \%$. In Fig. 21a the results of low strength specimens are not understandable that is why in Fig. 21b the results are zoomed and presented again. However, all samples exhibited strain-hardening behavior where the shear stress always went up with increasing shear strain as in Fig. 21a and b. This type of behavior is dilative or nonflow type behavior as denoted by Ishihara [40] and stable behavior as defined by Yamamuro and Lade [41]. It is notable here that in all specimens the phase transformation point was found (as in Fig. 21b).

The undrained monotonic peak shear strength within $15 \%$ axial strain versus percent of silt content is plotted in Fig. 22. Here the peak shear strength of clean sand at 78\% relative is assumed $3000 \mathrm{kPa}$. The monotonic loading machine have a restriction, it can produce maximum $1000 \mathrm{kPa}$, which was reached by this specimen at near about $4 \%$ axial strain (Fig. 18a). The peak shear strength is decreasing with increasing silt content till LFC, after LFC the strength becomes constant up to pure silt content. The brittleness index of specimens at initial relative density 30, 60 and 78\% are compared in Fig. 23. It could be concluded that the specimens containing silt close to LFC are more risky than others. Because the $I_{B}$ values of those specimens are going far down from 1 . For this studied sand-silt mixture, the LFC is 30 and the maximum $I_{B}$ was for specimens containing 20 to $40 \%$ silt, for different relative densities. However, specimens of $78 \%$ relative density showed stable behavior having $I_{B}$ close to 1 . It may be concluded that more catastrophic failure may occur if the percent silt content at a site is in between 20 and $40 \%$ and relative density is less than $78 \%$.

\section{Constant gross void ratio method}

The gross void ratio $(e)$ of a soil specimen is the ratio of the volume of void $\left(V_{V}\right)$ to the soil solids $\left(V_{S}\right)$ in the specimen. It can be expressed as a function of dry density $\left(\gamma_{d}\right)$ of the soil specimen and the specific gravity $\left(G_{S}\right)$ of the soil solids.

$$
\gamma_{d}=\frac{G_{S} \gamma_{w}}{1+e} \Rightarrow e=\frac{G_{S} \gamma_{w}}{\gamma_{d}}-1=\frac{G_{S} \gamma_{w}}{W_{d} / V}-1
$$

Specific gravity of sand and silt were 2.69 and 2.72 respectively. So the specific gravity of sand-silt mixtures will vary from 2.69 to 2.72 depending on the silt content. As the unit weight of water $\left(\gamma_{w}\right)$ is generally considered to be unique at normal temperature, the 


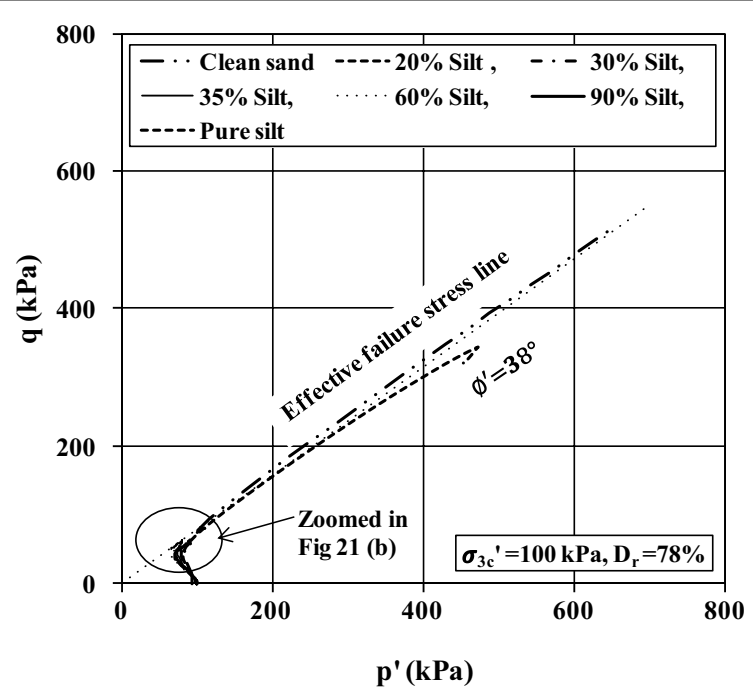

a

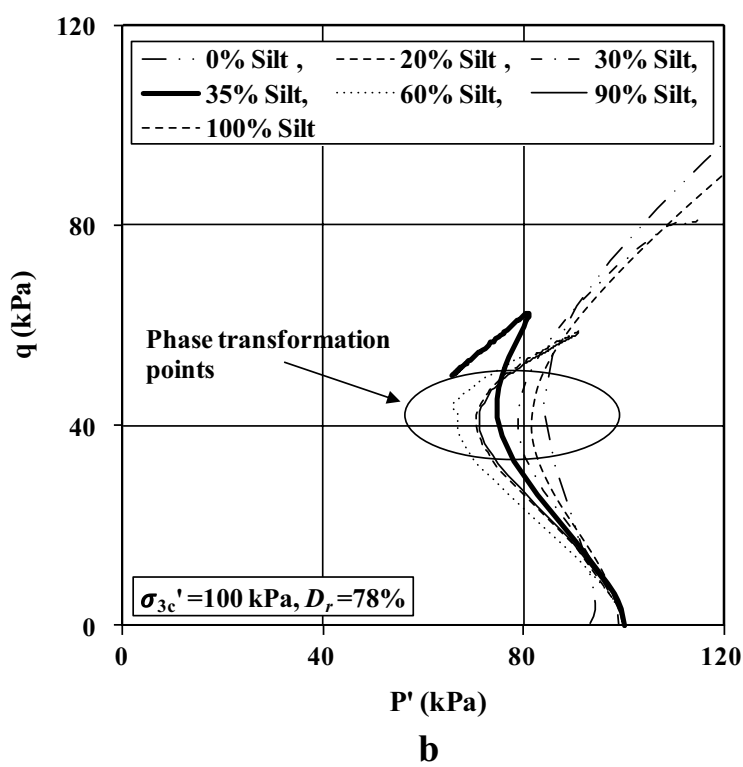

Fig. 21 Effective stress path of tested specimens at 78\% initial relative density; a silt content 0-100\% and b phase transformation points

void ratio $(e)$ solely depends on the dry weight $\left(W_{d}\right)$ of the soil used and the volume $(V)$ of the specimen, if the variation of specific gravity of sand-silt mixture is neglected.

In Fig. 24 undrained monotonic peak shear strength versus silt content graph for a constant void ratio 0.760 is shown. In this case total seven undrained monotonic triaxial tests have been conducted at different percent of silt content at constant gross void ratio 0.760 . It can be seen that the undrained monotonic peak strength parameter initially decreased and reached a minimum value at the LFC and thereafter the trend was reverse with further increase in silt content (Fig. 24). 


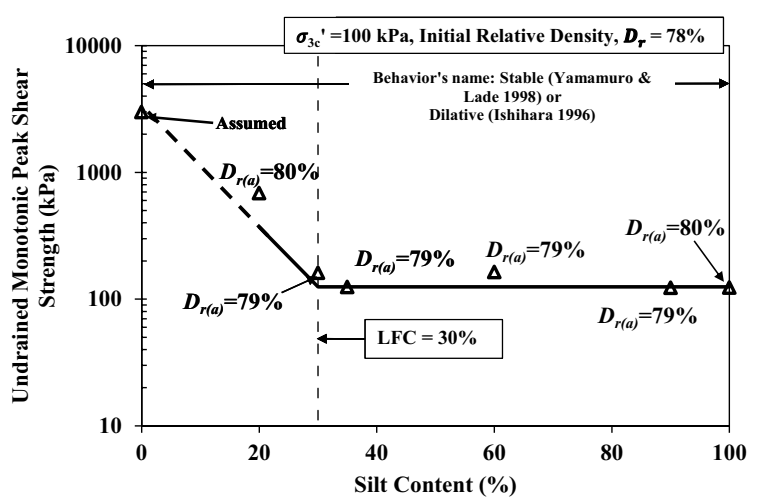

Fig. 22 Effect of silt content on undrained monotonic peak shear strength of sand-silt mixture at Canstant relative density of $78 \%$

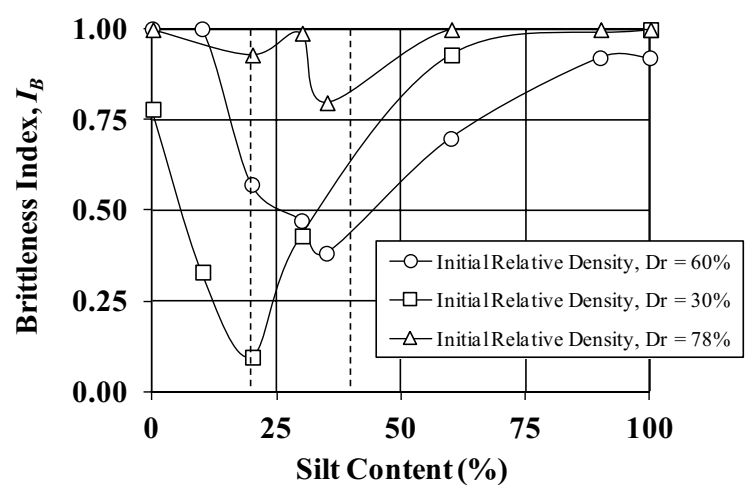

Fig. 23 Brittleness index of sand-silt mixtures at different initial relative densities

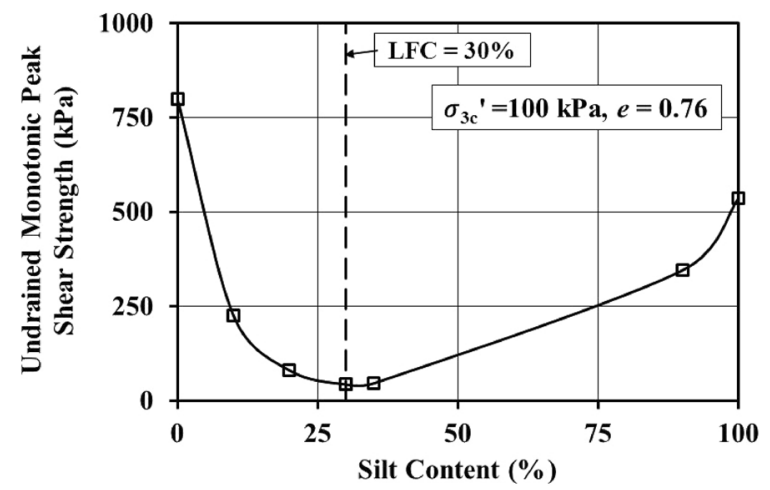

Fig. 24 Effect of silt content on undrained monotonic peak shear strength of sand-silt mixture at Canstant gross void ratio 0.76

\section{Discussion}

\section{Effect of dry density and relative density}

The effect of relative density and fines content on undrained peak shear strength of sand-silt mixtures is shown in Fig. 25. Reduction of the monotonic peak shear strength 


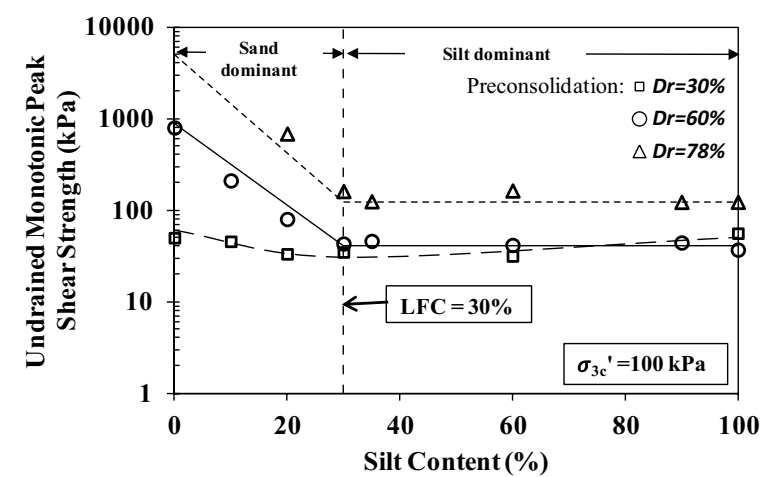

Fig. 25 Effect of silt content on undrained monotonic peak shear strength of sand-silt mixture at relative density of 30,60 and $78 \%$

with increasing silt content up to LFC was observed in this figure. For silt content more than LFC, monotonic peak shear strength remains constant with increasing silt content. Dry density is plotted against silt content for different relative densities in Fig. 26. It is seen that for same relative density, dry density increases slightly with increasing silt content up to LFC and again decreases with increasing silt content more than LFC.

\section{Permeability}

Permeability test results of sand-silt mixtures are exhibited in Fig. 27. At $D_{r}=60 \%$ (initial relative density), permeability decreases with increase in silt content till LFC thereafter the permeability become near about constant till pure silt content. In consolidated undrained test each specimen was consolidated at $100 \mathrm{kPa}$ confining pressure. After consolidation at $100 \mathrm{kPa}$, approximately $1-2$ and $4-6 \%$ changes occurred in relative density for sand dominant and silt dominant part (from initial $D_{r}=60 \%$ specimens) respectively. So some permeability tests were conducted at post consolidated relative density. In post-consolidation relative density similar behavior was observed and the post consolidation permeability was almost same as pre-consolidation permeability. From Fig. 26 (for $D_{r}=60 \%$ ) it is observed that after the LFC, dry density is decreasing with increasing silt content but permeability remain constant till pure silt. The static shear strength

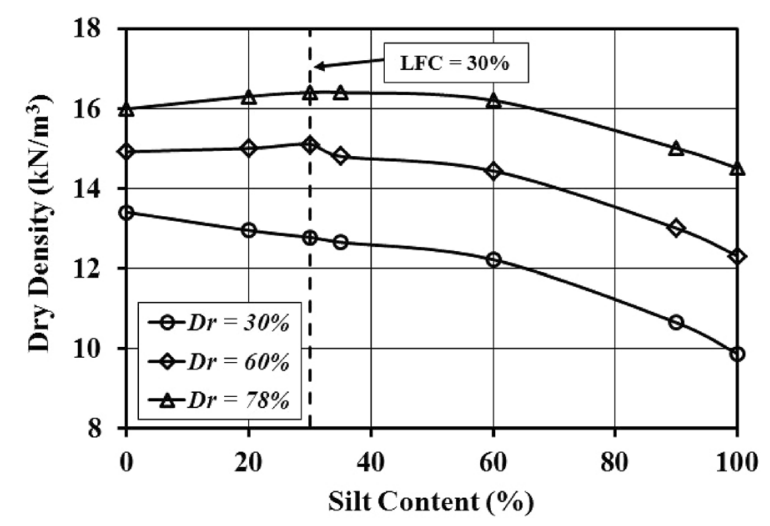

Fig. 26 Variation of dry density with silt content at constant relative density 


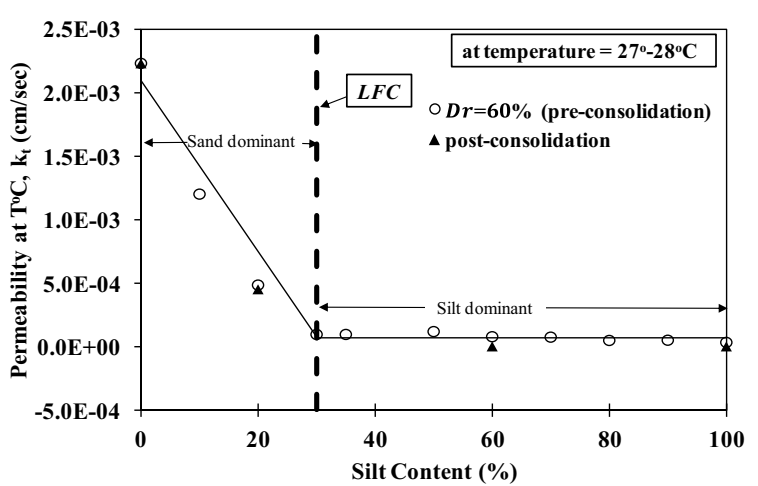

Fig. 27 Effect of silt content on coefficient of permeability of sand-silt mixture at Canstant relative density of $60 \%$

becomes constant after LFC for $D_{r}=60$ and $78 \%$. In case of $D_{r}=30 \%$ this concept could not be validated, because at $100 \mathrm{kPa}$ consolidation pressure the relative density after LFC became $50-65 \%$ (see Fig. 12) after consolidation.

\section{Response at shear}

During isotropical consolidation the sand particles get closer to each (because of medium dense sample) other. In silty sand, the silt particles located near contacts of sand particles would tend to slide into the void spaces (void among the sand particles) [41]. This requires that the silt particle size $\left(d_{50}\right)$ is much smaller than the pore size between the sand particles (sand particle size, $D_{50}$ ). Typically this requires that the particle size ratio $\left(R=D_{50} / d_{50}\right)$ is at least $6.5[11]$ and that the silt content is less than LFC. The particle size ratio $(R)$ of sand and silt used in this study is 9.23.

In case of clean sand (Fig. 15a), during application of deviator stress, initially the excess pore water pressure increases with axial strain, later it decreases and becomes negative. This can be explained by the probable structure as shown in Fig. 28. Figure 28 shows the schematic diagram of sand-silt mixture at different silt content. During loading the sand particles tend to split or roll over, as it is undrained triaxial test and the size of sand particles are greater than $75 \mu \mathrm{m}$, the particles cannot split or roll over easily (Fig. 28a). Consequently a large amount of suction pressure (negative excess pore water pressure) developed in the void. Due to the presence of more silt (10\% silt content) (Fig. 28b) in the specimen the silt particles fully confined within the sand particles (due to consolidation)

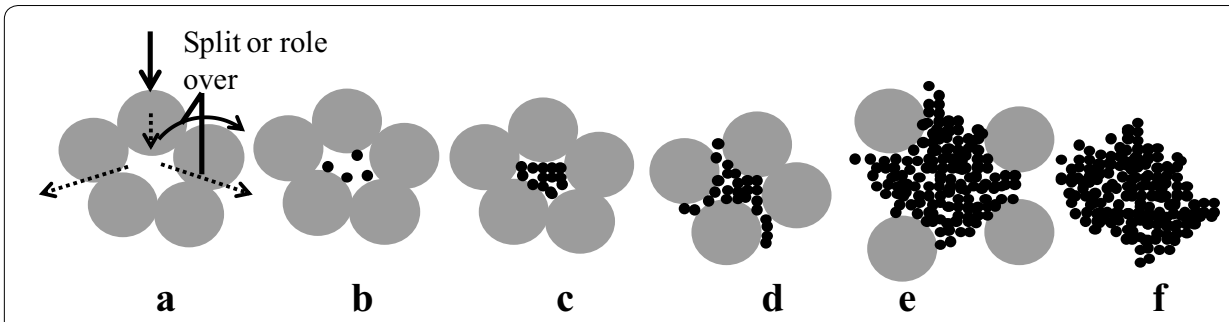

Fig. 28 Probable structure of sand-silt mixtures at shearing 
[41]. Here the grain size ratio is $R=D / d=9.23 \gg 6.5$. McGeary's [43] and Lade et al. [33] analyze data and showed that when $D / d \geq 7$, small particle migrate and fits in between the gaps of large particle and produce localized lowest silt density and localized maximum void ratio of silt $[11,44]$. This phenomenon continues until LFC. So at $10 \%$ silt content $(<$ LFC $)$ the silt particles cannot support the sand grains structure rather make obstacle (reduce permeability, see Fig. 27) to develop excess pore water pressure. So, less negative excess pore pressure developed at $10 \%$ silt content specimen (see Fig. 15). For $20 \%$ silt content specimen, the silt particles play the role of filler of intergranular voids, which reduce the permeability more (see Fig. 27); consequently much positive excess pore water pressure develops (see Fig. 15). For adding more silt (30\% silt content) (see Fig. 28c) the void spaces fully occupied with the silt particles, the silt particles start to support the sand particles. Here the voids are fully occupied by silt so the permeability becomes lower, that's why the more excess positive pore pressure developed (Fig. 15). That means at $30 \%$ silt content, the silt grains become active participants in the internal force chain. For adding more silt (60\% silt content) (Fig. 28e) the sand particle skeleton is virtually unstable without the silt grain. Figure $28 \mathrm{f}$ presents pure silt. At $D_{r}=60 \%$, after LFC the dry density decrease with the increase in silt content (see Fig. 26). So, variation of silt content has effect on density, but variation of silt content has no effect on static shear behavior [20]. At constant relative density the dry density is not constant after LFC (for increasing silt content) but the permeability was constant (see Fig. 27). The static shear strength becomes constant after LFC for $D_{r}=60 \%$ as well as for $D_{r}=78 \%$, though dry density decreases and permeability remain constant. So, it is very difficult to explain the behavior of sand-silt mixture containing silt content more than $30 \%$.

\section{Conclusion}

An experimental study on sand-silt mixture with different percent of silt content at different relative density was conducted. Undrained monotonic strain control triaxial tests were performed on sand-silt mixtures. Based on the experimental evidences, the following conclusions may be drawn:

1. Limiting fines content (LFC) was found to be the very important parameter to understand the behavior of sand-silt mixture. The behavior of sand-silt mixture changes approximately at LFC.

2. At constant relative density, increase in silt content decreases the undrained peak shear strength till LFC. After LFC the strength becomes near about same till pure silt sample. The reason of behavior could not be explained.

3. At constant global void ratio, the peak shear strength decreases with increase in silt content till LFC and for further increment of silt content the peak shear strength increases.

4. Sand-silt mixtures containing certain amount of silt which is near to the LFC showed flow type and brittle behavior. Failure of structure on this type of soil will be catastrophic during earthquake.

5. Permeability is decreasing with increasing silt content up to LFC. After the LFC, dry density is decreasing with increasing silt content but permeability remains constant till pure silt. 


\section{Authors' Contributions}

MEK has performed experiments, analyse data and written the manuscript. MJA has supervised the research and revised the manuscript. Both authors read and approved the final manuscript.

\section{Author details}

${ }^{1}$ Bangladesh University of Engineering and Technology, Dhaka 1000, Bangladesh. ${ }^{2}$ Department of Civil Engineering, Bangladesh University of Engineering and Technology, Dhaka 1000, Bangladesh.

\section{Acknowledgements}

The authors express their sincere gratitude for the financial assistance and laboratory facilities received from Bangladesh University of Engineering and Technology.

\section{Competing interests}

The authors declare that they have no competing interests.

\section{Publisher's Note}

Springer Nature remains neutral with regard to jurisdictional claims in published maps and institutional affiliations.

Received: 10 November 2016 Accepted: 28 June 2017

Published online: 21 July 2017

\section{References}

1. Olson SM, Stark TD, Walton WH, Castro G (2000) 1907 static liquefaction flow failure of the north Dike of Wachusett dam. J Geotech Geoenviron Eng 126(12):1184-1193

2. Fourie $A B$, Blight $G E$, Papageorgiou G (2001) Static liquefaction as a possible explanation for the Merriespruit tailing dam failure. Can Geotech J 38(4):707-719

3. Seed HB, Idriss IM, Arango I (1983) Evaluation of liquefaction potential using field performance data. J Geotech Eng 109(3):458-482

4. Seed RB, Harder LF (1990) SPT-based analysis of cyclic pore pressure generation and undrained residual strength. Proceedings Seed Memorial Symposium, Bi-Tech Publishers Ltd, pp 351-376

5. Yamamuro JA, Lade PV (1999) Experiments and modelling of silty sands susceptible to static liquefaction. Mech Cohes-Frict Mater 4(6):545-564

6. Yamamuro JA, Lade PV (1998) Steady-state concepts and static liquefaction of silty sands. J Geotech Geoenviron Eng 124(9):868-877

7. Robertson PK, Campanella RG (1985) Liquefaction potential of sands using the CPT. J Geotech Eng 111(3):384-403

8. Seed HB, Tokimatus K, Harder LF, Chung RM (1985) Influence of SPT procedures in soil liquefaction resistance evalutions. J Geotech Eng 111(2):1425-1445

9. Pitman TD, Robertson PK, Sego DC (1994) Influence of fines on the collapse of losse sands. Can Geotech J 31:728-739

10. Zlatovic S, Ishihara K (1995) On the influence of nonplastic fines on residul strength. 1st International conference on earthquake geotechnical engineering, Netherlands, pp 239-244

11. Thevanayagam S, Shenthan T, Mohan S, Liang J (2002) Undrained fragility of clean sands, silty sands and sandy silts. J Geotech Geoenviron Eng 128(10):849-859

12. Yang S, Lacasse S, Sandven R (2006) Determination of the transitional fines content of mixtures of sand and nonplastic fines. Geotech Test J 29(2):102-107

13. Sladen JA, D'Hollander RD, Krahn J (1985) The liquefaction of sands, a collapse surface approach. Can Geotech 」 22(4):564-578

14. Troncose JH, Verdugo R (1985) Silt content and dynamic behavior of tailing sands. 11 th International conference on soil mechanics and foundation engineering, California, pp 1311-1314

15. Chang NY, Yeh ST, Kaufman LP (1982). Liquefaction potential of clean and siltysand. In: Proceedings of 3rd international conference on earthquake microzonation, 2, pp 1017-1032

16. Kuerbis R, Negussey D, Vaid YP (1998) Effect of gradation and fines on static liquefaction of sands. In: Van Zyl DJA, Vick SG (eds) Hydraulic fill structure. ASCE, New York, pp 330-345

17. Belkhatir M, Arab A, Della N, Missoum H, Schanz T (2010) Liquefaction resistance of Chlef River silty sand: effect of low plastic fines and other parameters. Acta Polytechnica Hungarica 7(2):119-137

18. Belkhatir M, Schanz T, Arab A (2013) Effect of fines content and void ratio on the saturated hydraulic conductivity and undrained shear strength of sand-silt mixtures. Environ Earth Sci 70:2469

19. Dash HK, Sitharam TG (2011) Undrained cyclic and monotonic strength of sand-silt mixtures. Geotech Geol Eng 29:555-570

20. Dash HK, Sitharam TG (2011) Undrained monotonic response of sand-silt mixtures: effective of nonplastic fines. Geomech Geoeng Int J 6(1):47-58

21. Karim ME, Alam MJ (2014) Effect of non-plastic silt content on the liquefaction behavior of sand-silt mixture. Soil Dyn Eartha Eng 65:142-150

22. Bouferra R, Benseddiq N, Shahrour I (2007) Saturation and preloading effects on the cyclic behavior. Int J Geomech 7(5):396-401

23. Vaid YP, Chern JC (1983) Effect of static shear on resistance to liquefaction. Soils Found 23(1):47-60

24. Finn WD (2000) State-of-the-art of geotechnical earthquake engineering practice. Soil Dyn Earthq Eng 20(1-4):1-15 
25. Hazirbaba K (2005). Pore pressure generation characteristics of sands and silty sands: a strain approach. Dissertation presented for Ph.D. program to the Faculty of Graduate School at the University of Texas at Austin

26. Polito CP, Martin JR II (2001) Effects of nonplastic fines on the liquefaction resistance of sands. J Geotech Geoenviron Eng 127(5):408-415

27. Singh S (1994) liquefaction characteristics of Silt. Geotech Geol Eng 14(1):105-116

28. Vaid YP (1994) Liquefaction of silty soils. ASCE, Reston, pp 1-16

29. Georgiannou VN, Hight DW, Burland JB (1991) Undrained behavior of clayey sands in triaxial compression and extension. Soils Found 31(3):17-29

30. ASTM-4253-02 (2002) Standard test methods for maximum index density and unit weight of soils using a vibratory table. West Conshohocken, ASTM

31. Lee KL, Fitton JA (1968) Factors affecting the cyclic loading strength of soil. Vibration effects of earthquakes on soils and foundation, SPT 450:71-95

32. Head KH (1984) Manual of Laboratory Testing, vol 1. Pentech Press, London

33. Lade PV, Liggio CD, Yamamuro JA (1998) Effects of non-plastic fines on minimum and maximum void ratios of sand. Geotech Test J 21(4):336-347

34. Ladd RS (1978) Preparing test specimens using under compaction. Geotech Test J 1(1):16-23

35. ASTM-D4767-02 (2002) Standard test method for consolidated undrained triaxial compression test for cohesive soils. West Conshohocken, ASTM

36. Consoli NC, Johann AD, Gauer EA, Santos VR, Moretto RL, Corte MB (2012) Key parameters for tensile and compressive strength of silt-lime mixtures. Géotech Lett 2(3):81-85

37. Fredlund DG, Rahardjo H (2007) Soil mechanics for unsaturated soils. Wiley, New York

38. Khalili N, Geiser F, Blight GE (2004) Effective stress in unsaturated soils: review with new evidence. Int J Geomech 4(2):115-126

39. Rahman MM, Lo SR (2014) Undrained behavior of sand-fines mixtures and their state parameter. J Geotech Geoenviron Eng 140(7):1-12

40. Ishihara K (1996) Soil behaviour in earthquake geotechnics. Oxford Science Publications, Oxford

41. Yamamuro JA, Lade PV (1997) Static liquefaction of very loose sands. Can Geotech J 34(6):905-917

42. Rees SD (2010) Effect of fines on the undrained behavior of Christchurch sandy soils. University of Canterbury Christchurch, Christchurch

43. McGeary's RK (1961) Mechanical packing of spherical particles. J Am Ceram Soc 44(10):513-522

44. Thevanayagam S (2000) Liquefaction potential and undrained fragility of silty soils. 12WCEE 2000: 12th world conference on earthquake engineering, New Zealand Society for Earthquake Engineering, Auckland, pp 1-8

\section{Submit your manuscript to a SpringerOpen ${ }^{\circ}$ journal and benefit from:}

- Convenient online submission

- Rigorous peer review

- Open access: articles freely available online

- High visibility within the field

- Retaining the copyright to your article

Submit your next manuscript at $\boldsymbol{\nabla}$ springeropen.com 